\section{Brain, Behavior and Fvolution}

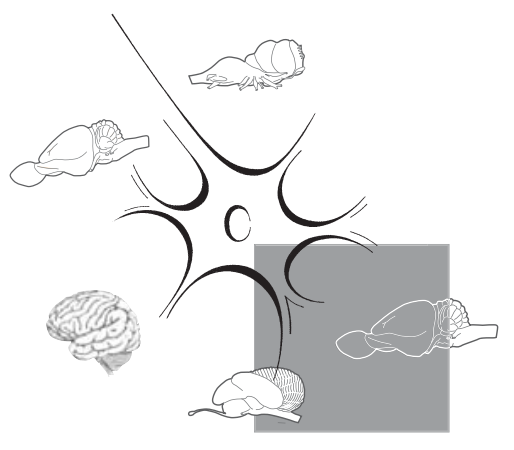

With our five senses, we humans and fellow amniotes live in a relatively impoverished sensory world. Most other vertebrates possess two additional senses mediated by their lateral line system. This lateral line consists of multiple receptor organs distributed in lines along the body surface, each comprising a cluster of secondary sensory cells (hair cells) and their supporting cells [Northcutt, 1997; Schlosser, 2002a; Ghysen and Dambly-Chaudière, 2007]. Mechanoreceptive sensory organs (neuromasts) detect water movements along the body surface, while electroreceptive sensory organs (ampullary organs) allow the perception of electric fields. A lateral line system with both types of receptor organs is found in most vertebrate taxa and, thus, appears to be a primitive character of vertebrates. However, several vertebrate groups such as amniotes and some direct developing amphibians have secondarily lost the entire lateral line system. Other groups retain the lateral line system but have lost some of its components [Northcutt, 1997; Schlosser, 2002b]. Mechanoreceptive lateral line organs were, for example, lost in some caecilians (limbless amphibians), whereas electroreceptive lateral line organs were lost in anurans and in the neopterygian fishes (teleosts, gars and bowfin). Electroreceptors then re-
Highlights and Perspectives on Evolutionary Neuroscience

Brain Behav Evol 2012;79:73-74

Published online: February 8, 2012

\title{
Evolution of Sensory Development - Lessons from the Lateral Line
}

\author{
Gerhard Schlosser \\ Zoology, School of Natural Sciences, National University of Ireland Galway, Galway, Ireland
}

evolved at least twice independently in various teleosts [Bullock et al., 1983]. Recently published insights into lateral line development [Modrell et al., 2011] now provide important new clues for reconstructing the developmental changes underlying some of these evolutionary modifications.

Embryonically, the receptor organs of the lateral line are thought to originate from a group of lateral line placodes, which also give rise to the sensory neurons innervating the receptors. Grafting and ablation experiments in the axolotl (Ambystoma mexicanum) demonstrated that lateral line placodes give rise to both neuromasts and ampullary organs [Northcutt et al., 1995]. However, it has so far remained unresolved whether embryonic development in other vertebrates follows a similar pattern. A new study now describes development of the lateral line system in the paddlefish Polyodon spathula [Modrell et al., 2011]. This chondrostean fish, closely related to sturgeons, has the largest number of ampullary organs among all living vertebrates, covering extensive regions of the head. Combined evidence from histological sections, scanning electron microscopy, Eya and Six family gene expression patterns, and DiI labelling of lateral line placodes strongly suggests that in Polyodon, as in Ambystoma, electroreceptors as well as mechanoreceptors originate from lateral line placodes. Because this pattern of lateral line development is shared between actinopterygians (Polyodon) and sarcopterygians (Ambystoma), Modrell et al. [2011] propose that it is most likely primitive for bony fishes and possibly even for gnathostomes or vertebrates since lateral line organs in cartilaginous fishes and lampreys are probably homologous.

Contrary to these conclusions, a recent study has suggested that electroreceptors in sharks are derived from neural crest [Freitas et al., 2006]. However, this claim is based on the expression of markers (Sox8, HNK1) that are not strictly confined to the neural crest, and it is not supported by any lineage studies. The neural crest has also been proposed to contribute to neuromast development in anurans and zebrafish [Collazo et al., 1994]. However, the fate mapping data provided in the latter study were compatible with the possibility that neural crest cells merely contribute glial cells associated with the lateral line and, thus, could not rule out an entirely placodal origin for neuromasts. Indeed, imaging studies in transgenic zebrafish (with claudinB-GFP-labelled lateral line primordia and FoxD3GFP-labelled neural crest) indicate that neuromasts are derived entirely from the

\section{KARGER}

Fax +4161306 1234 E-Mail karger@karger.ch www.karger.com www.karger.com/bbe
Dr. Gerhard Schlosser

Zoology, School of Natural Sciences and Regeneration Medicine Institute (REMEDI)

National University of Ireland, Galway

University Road, Galway (Ireland)

Tel. +35391 495 978, E-Mail gerhard.schlosser@ nuigalway.ie 
placodally derived migrating lateral line primordium, whereas neural crest-derived glial cells become associated with the outgrowing lateral line nerves, which track the primordium [Gilmour et al., 2002; Haas and Gilmour, 2006].

Taken together with the new study by Modrell et al. [2011], these data strongly suggest that the ancestral condition, at least in bony fishes but probably in all vertebrates, is that lateral line placodes alone give rise to all receptor organs and sensory neurons of the lateral line system. It will be interesting to see whether this also holds true for those teleosts, which re-evolved electroreception. In contrast to the electroreceptors of other actinopterygians and sarcopterygians, which use voltage-gated ion channels in the apical membrane to respond to cathodal stimuli, teleost electroreceptors use voltage-gated ion channels in the basal membrane to respond to anodal stimuli [Bodznick, 1989]. Teleost electroreceptors are, thus, probably not homologous to the electroreceptors of other vertebrates. How did they evolve? Since they are innervated by the lateral line nerves and develop in regions flanking the mechanoreceptive neuromasts [Northcutt, 1997], the latter are the most promising candidates for evolutionary precursors. The fact that neuromast hair cells also use voltage-gated ion channels in their basal membrane to trigger neurotransmitter release lends further weight to this scenario [Bodznick, 1989]. However, some previous studies proposed that electroreceptors in teleosts have an epidermal origin and are merely induced by lateral line nerves [Roth, 1986, 2003; Vischer, 1995]. This, if corroborated by further experimental studies, would instead suggest an evolutionary origin from epidermal cells.

Interestingly, a similar scenario has been proposed for the evolution of another type of placode, the epibranchial placodes. These mostly give rise to sensory neurons, which innervate sensory receptors of nonplacodal origin (e.g. taste buds derived from endoderm or ectoderm). However, the epibranchial placodes share a common embryonic origin with the lateral line plac- odes from a posterior placodal area. In addition, they give rise to some hair cell-like receptors in the paratympanic organ of chick embryos. Based on these observations it was suggested that epibranchial placodes may ancestrally have given rise to both secondary receptor cells and sensory neurons, lost their ancestral receptors during subsequent evolution, and eventually acquired new receptor cells of different embryonic origin [Baker et al., 2008]. Unfortunately, comparative studies will not allow us to test this scenario for epibranchial placodes since all extant vertebrates display the proposed derived condition. In the case of teleost electroreceptors, however, comparative studies provide us with good evidence on how lateral line placodes developed ancestrally in bony fishes. Lineage studies in the catfish or other electroreceptive teleosts are now needed to resolve the embryonic origin of electroreceptors in teleosts. Taken together, these two lines of evidence will provide important new insights into the evolution of sensory development for the lateral line.

\section{References}

Baker CV, O’Neill P, McCole RB (2008): Lateral line, otic and epibranchial placodes: developmental and evolutionary links? J Exp Zoo$\log$ B Mol Dev Evol 310:370-383.

Bodznick D (1989): Comparisons between electrosensory and mechanosensory lateral line systems; in Coombs S, Görner P, Münz H (eds): The Mechanosensory Lateral Line. New York, Springer, pp 653-678.

- Bullock TH, Bodznick DA, Northcutt RG (1983): The phylogenetic distribution of electroreception: evidence for convergent evolution of a primitive vertebrate sense modality. Brain Res Rev 6:25-46.

Collazo A, Fraser SE, Mabee PM (1994): A dual embryonic origin for vertebrate mechanoreceptors. Science 264:426-430.

-Freitas R, Zhang G, Albert JS, Evans DH, Cohn MJ (2006): Developmental origin of shark electrosensory organs. Evol Dev 8:74-80.
Ghysen A, Dambly-Chaudiere C (2007): The lateral line microcosmos. Genes Dev 21:21182130.

Gilmour DT, Maischein HM, Nüsslein-Volhard C (2002): Migration and function of a glial subtype in the vertebrate peripheral nervous system. Neuron 34:577-588.

Haas P, Gilmour D (2006): Chemokine signaling mediates self-organizing tissue migration in the zebrafish lateral line. Dev Cell 10:673680.

Modrell MS, Bemis WE, Northcutt RG, Davis MC, Baker CV (2011): Electrosensory ampullary organs are derived from lateral line placodes in bony fishes. Nat Commun 2:496.
Northcutt RG (1997): Evolution of gnathostome lateral line ontogenies. Brain Behav Evol 50: 25-37.

Northcutt RG, Brändle K, Fritzsch B (1995): Electroreceptors and mechanosensory lateral line organs arise from single placodes in axolotls. Dev Biol 168:358-373.
Roth A (1986): Afferent nerve fibers induce electroreceptors in the skin of fish. Naturwissenschaften 73:264-266.

Roth A (2003): Development of catfish lateral line organs: electroreceptors require innervation, although mechanoreceptors do not. Naturwissenschaften 90:251-255.

Schlosser G (2002a): Development and evolution of lateral line placodes in amphibians. 1. Development. Zoology 105:119-146.

-Schlosser G (2002b): Development and evolution of lateral line placodes in amphibians. 2. Evolutionary diversification. Zoology 105: 177-193.

-Vischer HA (1995): Electroreceptor development in the electric fish Eigenmannia: a histological and ultrastructural study. J Comp Neurol 360:81-100. 